\begin{tabular}{|l|c|c|c|}
\hline Variable & \multicolumn{2}{|c|}{$\begin{array}{c}\text { At least one of ocular, nasal or } \\
\text { respiratory symptoms }\end{array}$} & \\
\hline & Work related & Not work related & p value \\
\hline $\mathrm{N}$ & 85 & 102 & \\
\hline Age in years, median (range) & $31.4(24.6-60.7)$ & $33.4(22.8-57.2)$ & 0.589 \\
\hline Male & $47(55.3)$ & $51(50.0)$ & 0.470 \\
\hline Ever smoked & $27(31.8)$ & $43(42.2)$ & 0.144 \\
\hline Atopic to common aeroallergen & $33(38.8)$ & $41(40.6)$ & 0.806 \\
\hline Sensitised to mouse proteins & $32(37.7)$ & $10(9.8)$ & $<0.001$ \\
\hline OH mouse allergy & $21(24.7)$ & $0(0.0)$ & $<0.001$ \\
\hline Job title & $20(23.5)$ & $29(28.4)$ & \\
& $58(68.2)$ & $64(62.8)$ & 0.720 \\
& $7(8.2)$ & $9(8.8)$ & \\
\hline
\end{tabular}

Abstract S117 Table 1

sensitised animal workers. Measurement of exposure to endotoxin levels in these workers is in progress.

\section{S118 CAN FRACTIONAL EXHALED NITRIC OXIDE HELP PREDICT ASTHMA IN BRITISH FOUNDRY WORKERS?}

${ }^{1}$ RE Wiggans, ${ }^{1}$ E Robinson, ${ }^{1} \mathrm{~S}$ Sumner, ${ }^{1} \mathrm{~A}$ Codling, ${ }^{2} \mathrm{~L}$ Lewis, ${ }^{1} \mathrm{CM}$ Barber. ${ }^{1}$ Health and Safety Laboratory, Buxton, UK; ${ }^{2}$ Northern General Hospital, Sheffield, UK

10.1136/thoraxjn-2016-209333.124

Background Foundry work may involve exposure to respiratory sensitisers and irritants. There is limited evidence for the use of $\mathrm{FE}_{\mathrm{NO}}$ in occupational settings, and particularly in foundries.

Aim To examine the usefulness of $\mathrm{FE}_{\mathrm{NO}}$ in identifying foundry workers at risk of asthma.

Methods Foundry workers undertook a respiratory questionnaire. Spirometry (Ndd Easy on-PC Spirometer, Zurich) and $\mathrm{FE}_{\mathrm{NO}}$ (NOBreath, Bedfont Scientific, Kent) were measured to ATS/ERS standards. The ATS upper limit of normal (ULN) of 50 parts per billion (ppb), or 45.9ppb for current smokers, determined the high $\mathrm{FE}_{\mathrm{NO}}$ category $\left(\mathrm{FE}_{\mathrm{NO}}>\mathrm{ULN}\right)$. Workers with $\mathrm{FE}_{\mathrm{NO}}>\mathrm{ULN}$ were compared with those with at least one workrelated respiratory symptom (WRRS) and those with obstructive lung function $\left(\mathrm{FEV}_{1} / \mathrm{FVC}<0.7\right)$ using Chi Square and Fisher's Exact Tests.

Results 351 workers (350 men, 99\%) participated. 350 workers had a valid $\mathrm{FE}_{\mathrm{NO}}$ performed. Arithmetic mean $\mathrm{FE}_{\mathrm{NO}}$ was 30.2ppb (95\% CI: 27.3-33.2); geometric mean (GM) $\mathrm{FE}_{\mathrm{NO}} 20.8$ (18.9-22.9) ppb.

$\mathrm{FE}_{\mathrm{NO}}$ exceeded the ULN in $61(17 \%)$ workers. Average age for the $\mathrm{FE}_{\mathrm{NO}}>\mathrm{ULN}$ group was 41.5 (95\% CI: 38.3-44.7), with a mean of $15.8(12.4-19.2)$ years working in the foundry industry.

Workers in the $\mathrm{FE}_{\mathrm{NO}}>\mathrm{ULN}$ group were significantly more likely to have a current diagnosis of asthma $(12 \%$ vs $5 \%$, $\mathrm{p}<0.05)$, have ever suffered allergies (55\% vs 31\%, p < 0.01), or report work-related shortness of breath $(3 \%$ vs $0 \%$, $\mathrm{p}<0.05)$.
Fourteen workers (4\%) had a $\mathrm{FE}_{\mathrm{NO}}>\mathrm{ULN}$ and WRRS (Figure1). Of these 14, only 2 (14\%) had a current diagnosis of asthma (Fisher's $\mathrm{p}=0.20)$. Eight $(2 \%)$ workers had a $\mathrm{FE}_{\mathrm{NO}}>$ $\mathrm{ULN}$ and $\mathrm{FEV}_{1} / \mathrm{FVC}<0.7$, though only $2(25 \%)$ had a current asthma diagnosis (Fisher's $\mathrm{p}=0.08$ ).

Conclusion A significant proportion of foundry workers have $\mathrm{FE}_{\mathrm{NO}}$ levels that exceed the ATS cut point for likely eosinophilic airway inflammation. Of these workers, most had a raised $\mathrm{FE}_{\mathrm{NO}}$ but no WRRS or obstructive lung disease. Only a minority of workers with $\mathrm{FE}_{\mathrm{NO}}>\mathrm{ULN}$ and either WRRS or obstruction had a current diagnosis of asthma. $\mathrm{FE}_{\mathrm{NO}}$ may be useful in identifying foundry workers at risk of asthma and warrants further study.

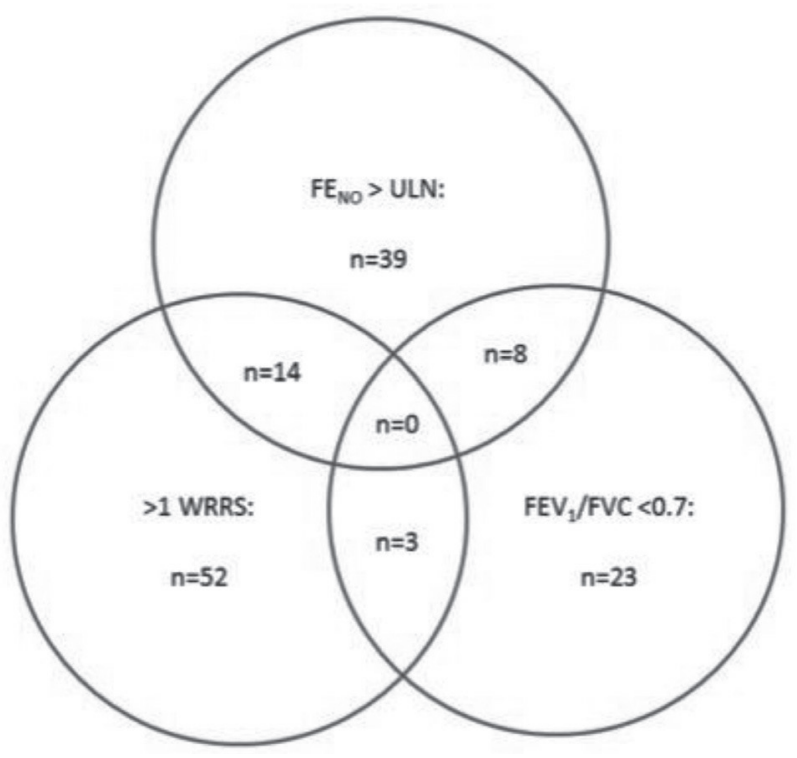

Abstract S118 Figure 1 Overlap between $\mathrm{FE}_{\mathrm{NO}}>\mathrm{ULN}$, work-related respiratory symptoms and obstructive spirometry in foundry workers. Total numbers in each group (\%of total): $\mathrm{FE}_{\mathrm{NO}}>\mathrm{ULN}$ : $\mathrm{n}=61(17 \%)_{i}>1$ WRRS: $\mathrm{n}=69(20 \%) ; \mathrm{FEV}_{1} / \mathrm{FVC}<0.7=\mathrm{n}=34(10 \%)$. $\mathrm{FE}_{\mathrm{NO}}>\mathrm{ULN}=$ $\mathrm{FE}_{\mathrm{NO}}$ above $50 \mathrm{ppb}$ or $45.9 \mathrm{ppb}$ in current smokers; WRRS = at least one work-related respiratory symptom 